University of Nebraska - Lincoln

DigitalCommons@University of Nebraska - Lincoln

$5-29-2020$

\title{
Coronavirus Food Assistance Program for Livestock Producers
}

Bradley Lubben

University of Nebraska-Lincoln, blubben2@unl.edu

Follow this and additional works at: https://digitalcommons.unl.edu/ageconfarmmgmt

Part of the Agribusiness Commons, Agriculture Law Commons, Entrepreneurial and Small Business Operations Commons, Management Information Systems Commons, Other Business Commons, Other Economics Commons, Other Immunology and Infectious Disease Commons, and the Virus Diseases Commons

Lubben, Bradley, "Coronavirus Food Assistance Program for Livestock Producers" (2020). Extension Farm and Ranch Management. 38.

https://digitalcommons.unl.edu/ageconfarmmgmt/38

This News Article is brought to you for free and open access by the Agricultural Economics Department at DigitalCommons@University of Nebraska - Lincoln. It has been accepted for inclusion in Extension Farm and Ranch Management by an authorized administrator of DigitalCommons@University of Nebraska - Lincoln. 


\section{Coronavirus Food Assistance Program for Livestock Producers}

By Brad Lubben

May 29, 2020

Congress and the president have approved multiple phases of COVID-19 assistance to date including the \$2.3 trillion CARES (Coronavirus Aid, Relief, and Economic Security) Act passed in March that provides financial support for agricultural producers as a small part of the overall relief.

While agricultural producers and agribusinesses are eligible for two programs administered through the Small Business Administration, including the Paycheck Protection Program (PPP) and Economic Injury Disaster Loans (EIDLs), the primary support for agriculture is coming from USDA through the Coronavirus Food Assistance Program (CFAP). The CARES Act provided $\$ 9.5$ billion directly to the Secretary of Agriculture and provided $\$ 14$ billion in funding to replenish Commodity Credit Corporation (CCC) accounts. The Secretary has used the $\$ 9.5$ billion of CARES Act funding and $\$ 6.5$ billion to date of CCC funding to implement CFAP.

The CFAP program rolled out with rules and sign-up through USDA's Farm Service Agency (FSA) in late May. The program provides direct payments to producers of a range of crops and livestock based on market losses from January to April and continuing disruptions in the wake of the COVID-19 pandemic. Since the CFAP program utilizes both the CARES Act funding and CCC funding, the program includes multiple payment rates in the calculation of total support for a producer.

Livestock

Of the total $\$ 16$ billion in estimated CFAP spending, the majority is targeted to livestock producers to cover economic losses from price declines on sales during the period of January 15 - April 15 as well as the decline in market value of inventory. CFAP provides assistance to cattle, hog, sheep, dairy, and wool producers. Read the explanation below and see payment rates in Table 1.

- Cattle, Hogs, and Sheep. Producer assistance is split into multiple parts and payment rates. The first part is based on head sold between January 15 and April 15 that were in inventory or were offspring of animals in inventory as of January 15, 2020. The second part is based on the producer's highest level of unpriced inventory held between April 16 and May 14. The payment rates are also divided between class and size by species.

$\circ$ Cattle. The first part of the payment for sales during January 15-April 15 is paid at a rate of $\$ 92$ to $\$ 214$ per head based on class and size. The second part of the payment for inventory is paid at a rate of $\$ 33$ per head for all cattle.

- Hogs. The first part of the payment for sales during January 15-April 15 is paid at a rate of $\$ 28$ per pig (less than 120 pounds) sold and $\$ 18$ per hog (120 pounds or more). The second part of the payment for inventory is paid at a rate of $\$ 17$ per head held for all hogs and pigs.

- Sheep (lambs and yearlings - sheep less than 2 years old). The first part of the payment for sales during January 15-April 15 is paid at a rate of $\$ 33$ per head. The second part of the payment for inventory is paid at a rate of $\$ 7$ per head. 
- Dairy. The assistance provides payments to dairy producers for production in the first and second quarters of 2020. Total milk production for January-March (including dumped milk) is eligible for a $\$ 4.71$ per hundredweight payment. Total milk production for April-June is estimated as 1.014 times January-March production to account for expected increased production levels in the second quarter and is eligible for a $\$ 1.47$ per hundredweight payment.

- Wool. Assistance for wool producers is paid on "eligible inventory", which is equal to the lesser of a producer's unpriced inventory as of January 15, 2020 or 50\% of 2019 production. As with other commodities the payment is split, although it is based on the same quantity. The first part of the payment is $\$ 0.71$ per pound on $50 \%$ of eligible inventory while the second part of the payment is $\$ 0.78$ on $50 \%$ of eligible inventory. This equates to an average payment rate of $\$ 0.745$ per pound paid on $100 \%$ of eligible inventory, all for clean, graded wool. For greasy, non-graded wool, the payment rates are $\$ 0.36$ and $\$ 0.39$ per pound respectively for an average of $\$ 0.375$ per pound.

Sign-up and Analysis

While sign-up for CFAP began on May 26 and is on-going through August 28 through FSA offices, there may still be some questions to be answered along the way. USDA addressed one of initial questions with additional guidance on marketing contracts that do and don't qualify in terms of inventory that was unpriced. Inventory is not eligible if it was covered by marketing contracts that lock in a cash or futures price or a minimum cash. This would rule out most hedging tools other than basis contracts or delayed/deferred pricing contracts. The ineligible contracts generally eliminate price risk, or at least the risk of futures market declines from which market losses were calculated in the first place to determine assistance.

The mechanics and math can be complicated, but FSA has produced a spreadsheet tool that can be used to calculate potential payments and apply for assistance. Details are available on USDA's CFAP website at farmers.gov/cfap. The downloadable Excel spreadsheet payment calculator is available through a link on this page or directly at the following UNL shortcut: go.unl.edu/fsacfaptool. The payment calculator will allow producers to plug in appropriate numbers for production, sales, and inventory to automate the calculations and estimate total payments across all commodities.

A simplified example provides insight on the calculation and methodology:

January 15 - April 15, 2020 sales of fed cattle: 1,000 head

Maximum April 16 - May 14, 2020 inventory January 15, 2020 inventory: 2,000 head

Portion of cattle inventory unpriced between April 16 - May 14, 2020: 90\%

Eligible inventory $=$ unpriced inventory $=2000 * 90 \%=1800$

Part 1 payment $=$ Head sold ${ }^{\star}$ payment rate $=1,000 * \$ 214=\$ 214,000$

Part 2 payment $=$ eligible inventory ${ }^{\star}$ payment rate $=1800 * \$ 33=\$ 59,400$

Gross payment $=$ part 1 payment + part 2 payment $=\$ 214,000+\$ 59,400=\$ 273,400$

While the calculator will provide estimates of total payments, there are some important limitations to these estimates. Because overall funding is limited at present, the CFAP payment is structured into two 
parts, with $80 \%$ due upon approval and the remaining $20 \%$ paid later subject to potential prorating of payments if there are insufficient funds to cover the full amount.

Producers are also subject to payment eligibility, payment limit, and conservation compliance rules.

- Eligibility. Producers must have an average adjusted gross income from 2016-2018 of less than $\$ 900,000$ unless at least $75 \%$ of the AGI comes from farming, ranching, or forestry.

- Payment Limits. Producers are subject to an individual payment limit of $\$ 250,000$ across all eligible CFAP commodities (including crops and livestock). Corporate entities that normally face a single payment limit under other FSA programs have a special rule for CFAP assistance that increases the payment limit to $\$ 250,000$ times the number of shareholders that contribute substantial labor or management (at least 400 hours per year) up to a limit of 3 shareholder or $\$ 750,000$.

- Conservation compliance. As with other USDA farm programs, producers must be in compliance with conservation requirements including conservation of highly erodible lands and wetlands.

Considering the payment rules and payment structure, the above example can be continued:

$$
\begin{aligned}
\text { Maximum gross payment } & =\text { lesser of gross payment or payment limit } \\
& =\text { lesser of } \$ 273,400 \text { or } \$ 250,000 \text { (assuming one individual) } \\
& =\$ 250,000
\end{aligned}
$$

Initial payment $=$ maximum gross payment ${ }^{*} 80 \%=\$ 250,000 * 80 \%=\$ 200,000$

Potential remaining payment $=$ maximum gross payment $* 20 \%=\$ 200,000 * 20 \%=\$ 50,000$

Based on some general estimates of eligible crops and livestock in Nebraska, total CFAP payments could exceed more than $\$ 1$ billion, with more than $\$ 600$ million for livestock before any payment eligibility or limits are factored in.

Looking ahead, producers are assured of the initial $80 \%$ of the payment with at least a portion of the remaining 20\% to come. There are already efforts to pass another round of COVID-19 assistance in Congress. If additional assistance comes as widely expected, it could ensure full payments on the current CFAP program as well as pave the way for further assistance on additional 2020 production affected by on-going market losses.

In sum, the CFAP assistance will definitely help producers hurt by market price declines and market disruptions in the wake of the COVID-19 pandemic. The estimated \$1 billion of potential assistance will increase cash flow on the farm and ranch and will represent a major part of the farm income bottom line this year, but will certainly not make up for the full extent of market losses to date nor cover continued losses and challenges for the remainder of the 2020 production and marketing year. Watching for further legislative development will be a key part of the financial picture going forward. 
Table 1. CFAP Livestock Assistance Payment Rates

\begin{tabular}{|l|c|c|c|}
\hline Commodity & $\begin{array}{c}\text { Unit of } \\
\text { Measure }\end{array}$ & $\begin{array}{c}\text { CARES Payment } \\
\text { Rate (Sales) }\end{array}$ & $\begin{array}{c}\text { CCC Payment } \\
\text { Rate (Inventory) }\end{array}$ \\
\hline Feeder Cattle: Less than 600 Pounds & Head & $\$ 102.00$ & $\$ 33.00$ \\
\hline Feeder Cattle: 600 Pounds or More & Head & $\$ 139.00$ & $\$ 33.00$ \\
\hline Slaughter Cattle: Fed Cattle & Head & $\$ 214.00$ & $\$ 33.00$ \\
\hline Slaughter Cattle: Mature Cattle & Head & $\$ 92.00$ & $\$ 33.00$ \\
\hline All Other Cattle & Head & $\$ 102.00$ & $\$ 33.00$ \\
\hline Pigs: Less than 120 Pounds & Head & $\$ 28.00$ & $\$ 17.00$ \\
\hline Hogs: 120 Pounds or More & Head & $\$ 18.00$ & $\$ 17.00$ \\
\hline All Sheep Less than 2 Years Old & Head & $\$ 33.00$ & $\$ 7.00$ \\
\hline Dairy: Milk & Hundredweight & $\$ 4.71$ & $\$ 1.47$ \\
\hline Wool: Graded, Clean & Pound & $\$ 0.71$ & $\$ 0.78$ \\
\hline Wool: Non-Graded, Greasy & Pound & $\$ 0.36$ & $\$ 0.39$ \\
\hline
\end{tabular}

Brad Lubben is an extension associate professor and policy specialist in the Department of Agricultural Economics. 